\title{
Effects of Cattle Grazing on Shore Vegetation Of Fluctuating Water Level Reservoirs
}

\author{
G.R. HOFFMAN AND L.D. STANLEY
}

Highlight: Shore vegetation around Lakes Oahe and Sakakawea, mainstem Missouri River reservoirs, is a musaic of shifting plant populations that responds to a combination of limiting factors including water level fluctuations and cattle grazing. Shore vegetation is important as it provides some wildlife habitat and spawning habitat for certain fish species, reduces erosion, adds to the aesthetic value of the shore environment, and provides forage for cattle grazing. The present study was done in 1976 to document the effects of cattle grazing on shore vegetation at seven sites that were inundated for a prolonged period in 1975. Some of the dominant shore species were Horedeum jubatum, Agropyron smithii, A. repens, Chenopodium album, Iva xanthifolia, Kochia scoparia , Melilotus ssp., Polygonum achoreum, P. lapathifolium, Rumex crispus,, and Xanthium strumarium. Solanum rostratum and Grindelia squarrosa along with several other species were favored by grazing. Floristically, ungrazed plots were more similar than grazed plots when pairs of sites were compared. Total plant coverages inside exclosures at three sites on Pierre Shalederived soils ranged from $54 \%$ to $97 \%$ and biomass values ranged from $458 \mathrm{~g} \cdot \mathrm{m}^{-2}$ to $720 \mathrm{~g} \cdot \mathrm{m}^{-2}$, while outside exclosures at the same sites total plant coverages ranged from $11 \%$ to $82 \%$ and biomass values were $19 \mathrm{~g} \cdot \mathrm{m}^{-2}$ to $259 \mathrm{~g} \cdot \mathrm{m} .^{-2}$. At one site, on loessderived substrate, total plant coverages inside and outside the exclosure were $116 \%$ and $77 \%$ respectively, and biomass values were $606 \mathrm{~g} \cdot \mathrm{m}^{-2}$ inside and $210 \mathrm{~g} \cdot \mathrm{m}^{-2}$ outside the exclosure. All three sites on Lake Sakakawea are on glacial till-derived substrates, and plant coverages ranged from $128 \%$ to $155 \%$ inside exclosures where biomass values were $478 \mathrm{~g} \cdot \mathrm{m}^{-2}$ to $1,766 \mathrm{~g} \cdot \mathrm{m}^{-2}$. Outside the exclosures the total plant coverages were $24 \%$ to $144 \%$ and biomass values were $15 \mathrm{~g} \cdot \mathrm{m}^{-2}$ to $474 \mathrm{~g} \cdot \mathrm{m}^{-2}$.

Shore vegetation develops between periods of high water; thus annual fluctuations in water levels, along with cattle grazing as limiting factors, keep shore vegetation in an early seral stage. Minimizing both water level fluctuations and cattle grazing for a given reservoir during a given year, preferably a 2 -year period, would permit considerably more shore vegetational development. This regimen, if rotated among the six reservoirs, would over a period of years, benefit development of shore vegetation.

Cattle grazing is a major enterprise in the western North and South Dakotas. Along the Missouri River reservoirs in these states, cattle have ready access to both shore vegetation and water. While it has been recognized for many years that cattle grazing can decrease significantly the shore vegetation of ponds, lakes, and reservoirs (Gill and Bradshaw 1971; Kelting and Penfound 1950; Magadza 1970; Tiemeier 1951), the effect of cattle grazing on shore vegetation of the Missouri River reservoirs has not been studied previously.

Lakes Oahe and Sakakawea, mainstem Missouri River reser-

Authors are professor of biology and research associate. Department of Biology, University of South Dakota, Vermillion 57069.

This study was supported by funds from the U.S. Army Corps of Engineers, Operations Division, Omaha District.

Manuscript received January 24, 1978. voirs (Fig. 1), have fluctuating water levels that peak during the summers and reach low during the winters. Water fluctuation patterns vary from year to year in each reservoir and are quite dissimilar between the two reservoirs. For the years 1969-1975, the average water level fluctuations were $3.58 \mathrm{~m}(11.7 \mathrm{ft})$ and $3.45 \mathrm{~m}(11.3 \mathrm{ft})$ in Lakes Oahe and Sakakawea, respectively. Based on lake basin morphometry data of 1968 (U.S. Army Corps of Engineers 1971, 1972) these water level fluctuations translate to shore areas of 20,658 ha $(51,025$ acres $)$ and 19,422 ha $(47,972$ acres) for Lakes Oahe and Sakakawea, respectively. In 1975, when water reached record high levels in both reservoirs, 27,738 ha $(68,513$ acres) around Lake Oahe and 26,380 ha $(65,159$ acres) around Lake Sakakawea were inundated. Following high water, vegetation becomes established on the shores and survives until high water and/or cattle grazing

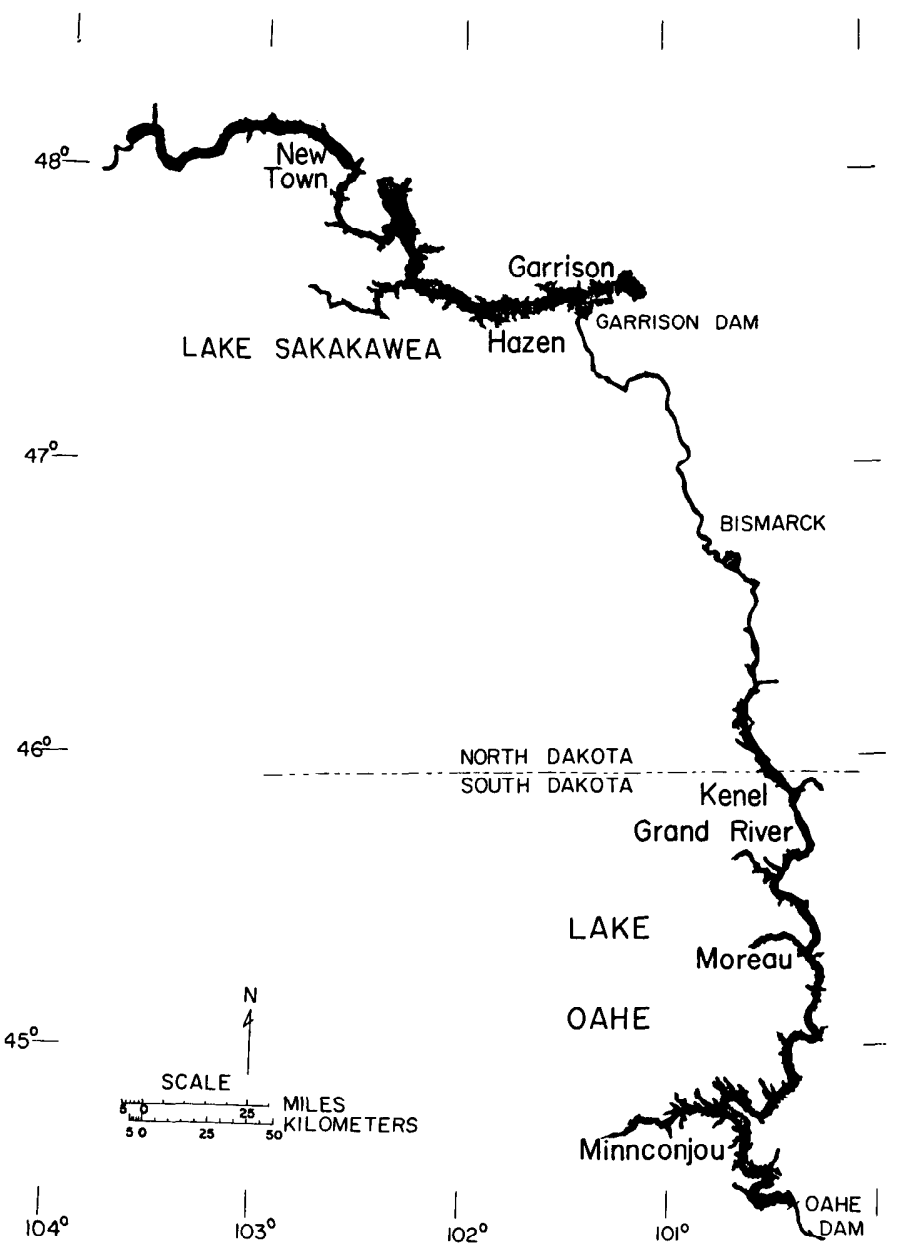

Fig. 1. Seven study sites on shores of Lakes Oahe and Sakakawea, mainstem Missouri River reservoirs. 
eliminate it. Reduced vegetative cover exposes the shore to enhanced erosion and reduces preferred spawning habitat for a number of important fish species in the reservoirs.

On the federally controlled land immediately surrounding Lake Sakakawea, a 6-month grazing period, May 1 to October 31 , is permitted. On improved pastures the stocking rate allowed is one animal unit/15 acres, and on native grassland the rate is one animal unit/30 acres. Additionally, for maximum sustained production of the vegetation, one half the year's plant growth must remain after the grazing season. The stated regulations for grazing around Lake Oahe are somewhat different. Here the grazing period is May 1 to November 1 , and winter grazing is permitted in lieu of summer grazing. Though stocking rates are not specifically stated, grazers are requested to comply with state regulations, strive to improve the grazing lands, and conform to all principles of good husbandry; overgrazing is not allowed (Operations Division, Corps of Engineers, Omaha District, personal communication).

Stated guidelines are obviously worthwhile for grazers. Parts of any grazed area will be more heavily utilized than others, and because of access to water, reservoir shores are areas of intense use. Because the shores are inundated regularly and the vegetation there is subject to drowning, it is somewhat more difficult to judge the impact of grazing. The ephemeral nature of the shore vegetation also makes it quite distinct from the upland steppe for which the grazing guidelines were actually written. The present study was done to document changes in shore vegetation as a result of cattle grazing along these two reservoirs.

\section{Methods}

The shore vegetation is a mosaic composed primarily of alien species that survive for various periods between high water. Vegetational changes occuring in these seral communities depend on such factors as source of disseminules, tolerance to flooding and/or water-logged substrates, timing of water level fluctuations in relation to phenological activities of plant species, and in some instances disturbance from cattle. Our study was done in 1976 following the record high water levels of 1975 during which most if not all the shore vegetation was drowned. Thus, most of the shore species encountered in our study became established late in 1975 or 1976 . Doing the study in 1976 provided some measure of uniformity among the sites inasmuch as all the shore was quite depleted of species during 1975 .

In 1973 and 1974 we constructed several cattle exclosures, seven of which were used in the present study. The exclosures are approximately $40 \times 80 \mathrm{~m}(44 \times 87 \mathrm{yd})$ with the long dimension perpendicular to the shoreline. All exclosures were constructed using steel posts planted about $10 \mathrm{~m}(11 \mathrm{yd})$ apart with four strands of barbed wire strung around the perimeter and clamped to each post. Corner posts were reinforced with additional stakes and wire. All cxclosures have been checked twice yearly for maintenance needs. The exclosures were planned so that at least half the area inside was shore area and other half upland steppe. During the summers, when water levels are high, at least part of the shore area of each exclosure is inundated. Cattle have ready access to all the area around each exclosure.

At each sampling site (Fig. 1) we estimated plant canopy coverages within $2 \times 5 \mathrm{dm}(7.9 \times 10.7$ in) plots (Daubenmire 1959). We sampled 30 plots at meter intervals along a tape parallel to the shoreline inside the exclosure. A duplicate set of plots was analyzed along a tape outside the exclosure and the same distance from the shoreline. Where canopy coverages were estimated, we also collected plant materials for biomass estimates. These were done by clipping at ground level all living vegetation rooted within ten $0.1 \mathrm{~m}^{2}\left(1.1 \mathrm{ft}^{2}\right)$ plots inside each exclosure. For shrubs, only current year twigs and leaves were collected. These plots were spaced $2 \mathrm{~m}(6.6 \mathrm{ft})$ apart along the same tapes used for coverage estimates. All plant material collected was placed in paper sacks and air-dried in the field. In the laboratory the material was dried further at $70^{\circ} \mathrm{C}$ for $48 \mathrm{hr}$, then weighed to the nearest $0.1 \mathrm{~g}$.

Voucher specimens of plants collected during this study were deposited in the University of South Dakota Herbarium.

\section{Results and Discussion}

The shore vegetation around both Lakes Oahe and Sakakawea is a mosaic of ephemeral plant communities that survive one or more years before being decimated by a combination of high water and/or cattle grazing. The shore communities consist primarily of seral species that become established either during the autumn or spring when water levels are low. At least part of the shore is inundated every year, eliminating some species annually, with more tolerant species persisting.

Minnconjou, Moreau, and Grand River sites on Lake Oahe occur on Pierre Shale-derived substrate which weathers into heavy clays or clay loams. The high clay content results in high water-holding capacity following inundation, or precipitation, but the same substrates become very hard and cracked when dry. Soil pH is above 7.0 at all three sites, and cation exchange capacities are between 29 and $31 \mathrm{meq} / 100 \mathrm{~g}$ with calcium and magnesium dominating the exchange complex. Owing to variable amounts of organic matter in the shore substrates, the amounts of phosphorus and nitrogen are variable, and not espcially high. The edaphic characteristics of the three sites are sufficiently similar that vegetational differences among the sites are not directly related to substrate characteristics. The similarity of each pair of stands was calculated using the familiar index of similarity:

$$
\text { I.S. }=\frac{2 c}{a+b} \times 100
$$

where I.S. is the index of similarity, $a$ is the total number of species in one stand, $b$ the total number of species in the second stand, and $c$ the number of species shared by the two stands. The value is multiplied by 100 to express the index as a percentage. Using total floristic lists from the above three sites, the indexes of similarity are the following: Minnconjou and Moreau = $37 \%$, Moreau and Grand River $=11 \%$, and Minnconjou and Grand River $=10 \%$. From ungrazed plots only, the indexes are the following: Minnconjou and Moreau $=40 \%$, Moreau and Grand River $=34 \%$, and Minnconjou and Grand River $=32 \%$. From grazed plots only, the indexes are the following: Minnconjou and Moreau $=23 \%$, Moreau and Grand River $=31 \%$, and Minnconjou and Grand River $=27 \%$.

Though chance is important in determining the composition of seral shore communities, there is considerable similarity among the three sites on Pierre Shale-derived substrates. Grazing reduced the similarities to some extent, as shown by the calculated indexes above. The Grand River site is the most heavily grazed of the three sites. It has the greatest abundance of Solanum rostratum and Grindelia squarrosa; both were more abundant on grazed plots at Grand River (Table 1). Important species on ungrazed plots at Grand River include Bromus japonicus, Chenopodium album, Helianthus annuus, Melilotus spp., Polygonum achoreum, and Hordeum jubatum. All but Hordeum were less abundant on grazed plots. Total coverage on grazed plots at Grand River was only slightly less than on ungrazed plots (Table 1). Total biomass, however, was reduced by nearly $50 \%$ on grazed plots at this site (Table 2 ). 
Table 1. Average canopy coverages (\%) of plants in grazed (G) and ungrazed (U) plots along shores of Lake Oahe and Sakakawea. Only those species are included that had an average coverage of at least $1 \%$ at one site.

Sites and percent canopy coverages

Species

\begin{tabular}{|c|c|c|c|c|c|c|}
\hline Minnconjou & Moreau & Grand River & Kenel & Hazen & Garrison & New Town \\
\hline G & G & G & G & G & G & G \\
\hline
\end{tabular}

Grasses:

Agropyron repens (quackgrass) ${ }^{1}$

Agropyron smithii (western wheatgrass)

Agrostis hyemalis (ticklegrass)

Alopecurus arundinaceus (garrison creeping foxtail)

Beckmannia syzigachne (American sloughgrass)

Bromus japonicus (Japanese chess)

Enchinocloa crusgalli (barnyard grass)

Hordeum jubatum (foxtail barley)

Panicum capillare (witchgrass)

Poa palustris (fowl bluegrass)

Poa pratensis (Kentucky bluegrass)

Sphenopholis obtusata (prairie wedgegrass)

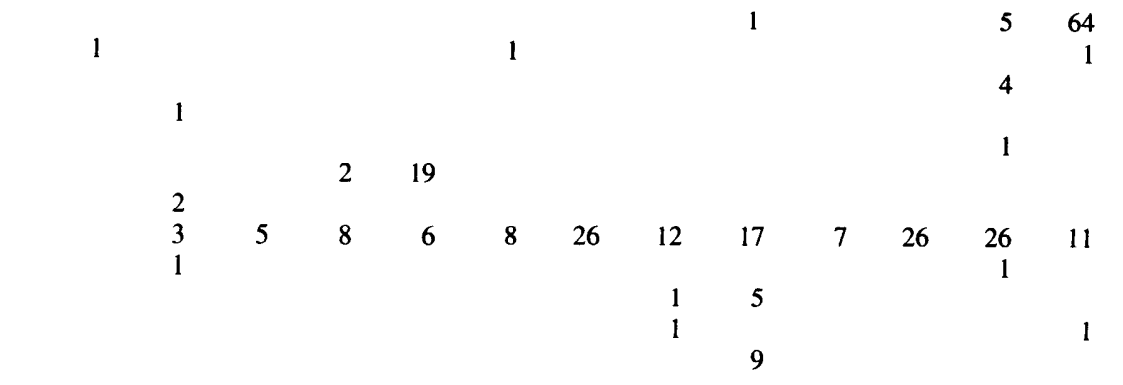

Shrubs and Forbs:

Achillea millefolium (yarrow)

Amaranthus albus (tumbleweed)

A. graecizans (prostrate pigweed)

Artemisia biennis (biennial wormwood)

A. frigida (pasture sage-brush)

Atriplex rosea (redscale)

Chenopodium album (goosefoot)

C. hybridum (maple leaved goosefoot)

Cirsium undulatum (wavy leaved thistle)

Conyza canadensis (horseweed)

Descurainia sophia (herb sophia)

Grindelia squarrosa (gumweed)

Hedeoma hispida (false pennyroyal)

Helianthus annuus (common sunflower)

Iva xanthifolia (marshelder)

Kochia scoparia (fireweed)

Lactuca serriola (prickly lettuce)

Lepidium densiflorum (peppergrass)

Medicago lupulina (black medic)

Melilotus spp. (sweet clovers) ${ }^{2}$

Plantago eriopoda (alkali plantain)

Plantago major (common plantain)

Polygonum achoreum (erect knotweed)

$P$. convolvulus (black bindweed)

$P$. lapathifolium (nodding willow weed)

$P$. ramosissimum (bushy knotweed)

Potentilla norvegica (rough cinquefoil)

Ratibida columnifera (coneflower)

Rumex crispus (sour dock)

Rumex maritimus (golden dock)

Salsola iberica (Russian thistle)

Sisymbrium altissimum (tumbling mustard)

Solanum rostratum (buffalo bur)

Sonchus arvensis (field sow-thistle)

Thlaspi arvense (pennycress)

Verbena bracteata (prostrate vervain)

Xanthium strumarium (cocklebur)

Total cover, percent

Total number of species

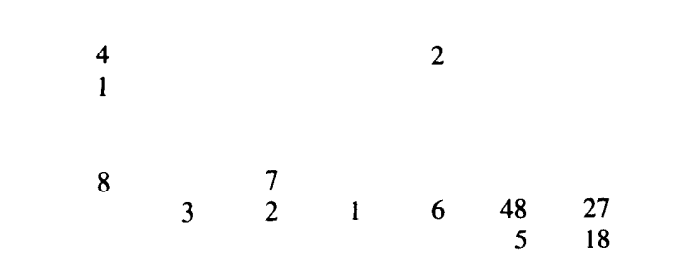

1

$\begin{array}{rrrr}1 & 1 & 1 \\ 1 & 18 & \\ 1 & 2 & 6\end{array}$

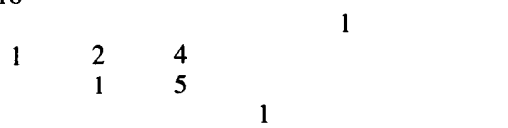

$2 \quad 2$

1

$\begin{array}{llllll}2 & 7 & 6 & 1 & 2 & 13\end{array}$

25

10

$9 \quad 27$

3

1

30

2

$\begin{array}{lllll}1 & 47 & 1 & 2 & 4\end{array}$

$\begin{array}{rrrrrr}33 & 1 & 2 & & 9 & 4 \\ 5 & 28 & 10 & 97 & 4 & 2 \\ 5 & 3 & 1 & 2 & 20 & 1\end{array}$

$\begin{array}{lllllll}6 & 10 & 47 & 3 & 1 & 3 & 12\end{array}$

3

11

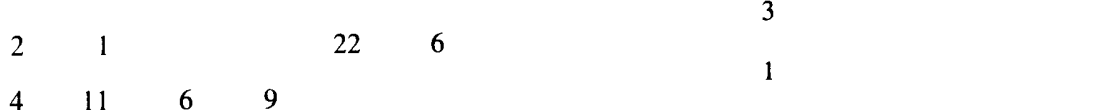

' Plant nomenclature follows Van Bruggen (1976).

"Included here are Melilotus albus (white sweet clover) and Melilotus officinalis (yellow sweet clover).

Rumex crispus often dominates shore vegetation the first year following high water. It germinates and establishes on the bare shore in late summer as the water level recedes, remains in rosette form overwinter, then forms dense stands the following growing season. Cattle do graze the species. At the Moreau site Rumex crispus had $47 \%$ and $10 \%$ coverage on ungrazed and grazed plots, respectively. At Minnconjou it had 6\% coverage on ungrazed plots and was absent from grazed plots (Table 1).
At Moreau Hordeum jubatum, Atriplex rosea, Polygonum ramossisimum, Thlaspi arvense, and Xanthium strumarium were also important on ungrazed plots and were reduced or absent on grazed plots. Contrary to results obtained at Grand River and Minnconjou, both Melilotus ssp. and Polygonum achoreum were more abundant on grazed plots at Moreau. Total coverage at Moreau was $97 \%$ and $43 \%$ on ungrazed and grazed plots, respectively. Biomass at Moreau was $720 \mathrm{~g} . \mathrm{m}^{-2}$ and 19 73 g.m ${ }^{2}$ on ungrazed and grazed plots respectively (Table 2). 
Table 2 Biomass $\left(\mathrm{g} \cdot \mathrm{m}^{2}\right)$ present in grazed and ungrazed plots of shore vegetation.

\begin{tabular}{lccccccc}
\hline \hline $\begin{array}{l}\text { Condition } \\
\text { of plots }\end{array}$ & \multicolumn{3}{c}{ Sites and biomass } \\
\cline { 2 - 7 } & Minnconjou & Moreau & Grand River & Kenel & Hazen & Garrison & New Town \\
\hline Grazed & 19 & 173 & 259 & 210 & 85 & 15 \\
Ungrazed & 378 & 720 & 458 & 606 & 478 & 1766 \\
\hline
\end{tabular}

Minnconjou was the least productive site judged by both coverage and biomass estimates. Total coverage was $54 \%$ and $11 \%$ on ungrazed and grazed plots, respectively; and biomass was $378 \mathrm{~g} \cdot \mathrm{m}^{-\overline{2}}$ and $19 \mathrm{~g} \cdot \mathrm{m}^{-2}$ on ungrazed and grazed plots, respectively. Atriplex rosea, Amaranthus albus, Rumex crispus, and Xanthium strumarium were all important on ungrazed plots and absent on grazed plots at Minnconjou. Melilotus spp. and Thlaspi arvense were also important on ungrazed plots and were considerably reduced by grazing (Fig. 2). No species encountered at Minnconjou was more abundant on grazed than on ungrazed plots.

The Kenel site occurs on a loess-derived substrate that has weathered into a relatively fertile silt loam soil. That the soil is quite fertile is attested to by not only soil analyses but also by the lack of response in production following addition of nitrogen, phosphorus, and potassium at the Kenel site (Hoffman and Stanley 1977). Hordeum jubatum, Chenopodium album, C. hybridum, Kochia scoparia, and Rumex crispus were all abundant on ungrazed plots. Total plant coverage was $116 \%$ and $77 \%$ on ungrazed and grazed plots, respectively, at Kenel (Table 1). Biomass estimates were $606 \mathrm{~g} \cdot \mathrm{m}^{-2}$ and $210 \mathrm{~g} \cdot \mathrm{m}^{-2}$ on ungrazed and grazed plots, respectively. Chenopodium album was much more abundant on grazed than on ungrazed plots and accounted for more than $50 \%$ of the coverage and biomass on grazed plots.

The three sites on Lake Sakakawea shore occur on glacial till-derived substrates having textures of loam at Hazen and clay loam at both Garrison and New Town. Floristic similarities among the three sites, lumping data from grazed and ungrazed plots and calculating as above for the Lake Oahe sites, yielded the following: Hazen and Garrison $=36 \%$, Hazen and New Town $=41 \%$, and Garrison and New Town $=24 \%$. The same indexes representing only grazed plots were the following: Hazen and Garrison $=28 \%$, Hazen and New Town $=24 \%$, and Garrison and New Town $=29 \%$. Similarity indexes represent-

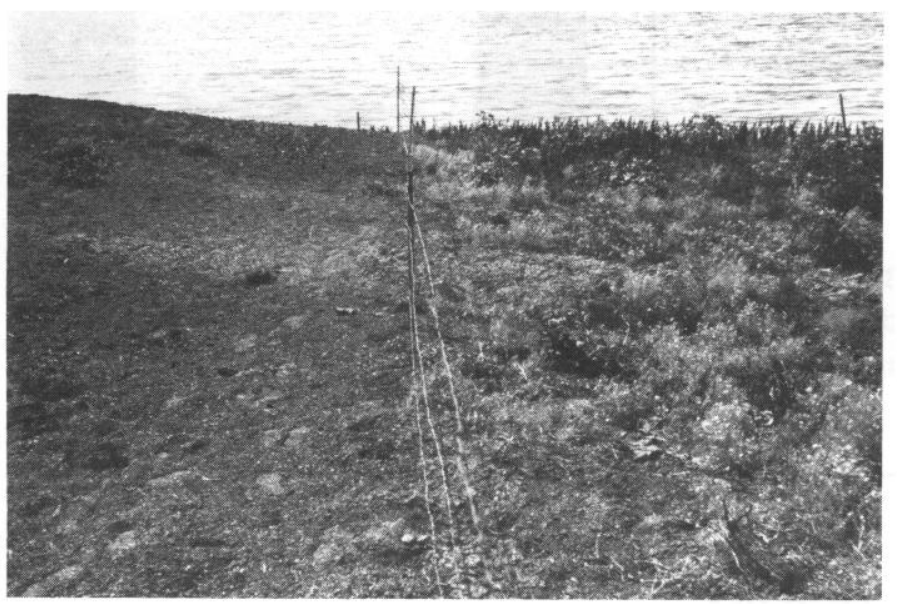

Fig. 2. Shore vegetation at Minnconjou site. Inside exclosure, right, vegetation is dominated by Rumex crispus, Xanthium strumarium, Melilotus spp., Atriplex rosea, and Thlaspi arvense. Outside the exclosure, left of fence, cattle have removed most of the vegetation. ing only ungrazed plots were Hazen and Garrison $=32 \%$, Hazen and New Town $=42 \%$, and Garrison and New Town $=$ $30 \%$. Floristically, ungrazed plots were more similar than grazed plots, consistent with results obtained from the Lake Oahe sites.

Important species on ungrazed plots at Hazen were Hordeum jubatum, Sphenopholis obtusata, Poa palustris, Chenopodium album, Descurainia sophia, Melilotus spp., and Polygonum lapathifolium, all of which were less abundant or absent on grazed plots. Polygonum achoreum was much more abundant on grazed plots with $33 \%$ coverage compared to only $1 \%$ coverage on ungrazed plots (Table 1). Potentilla norvegica was also somewhat more abundant on grazed than ungrazed plots. Total plant coverage at Hazen was $155 \%$ and $72 \%$ on ungrazed and grazed, plots respectively (Table 1). Biomass was 478 g.m $\mathrm{m}^{-2}$ and $85 \mathrm{~g} . \mathrm{m}^{-2}$ on ungrazed and grazed plots, respectively (Table 2).

Important species on ungrazed plots at Garrison were Hordeum jubatum, Polygonum lapathifolium, and Rumex crispus. All three species were much less abundant on grazed plots. Small amounts of Grindelia squarrosa, Medicago lupulina, and Polygonum achoreum were present only on grazed plots at Garrison. Total plant coverages at Garrison were $137 \%$ and $24 \%$ on ungrazed and grazed plots, respectively. Biomass was $1,766 \mathrm{~g} . \mathrm{m}^{-2}$ on ungrazed plots and $15 \mathrm{~g} . \mathrm{m}^{-2}$ on grazed plots. Polygonum lapthifolium accounted for much of the coverage and biomass on the ungrazed plots.

New Town was the only site at which total plant coverage was greater on grazed than on ungrazed plots, though the difference was slight. Biomass, however, exhibited the same trend as that of other sites: 911 g.m $\mathrm{m}^{-2}$ and 474 g.m $\mathrm{m}^{-\hat{2}}$ on ungrazed and grazed plots, respectively. Agropyron repens dominated the ungrazed plots along with Hordeum jubatum, Chenopodium album, and Iva xanthifolia. Of these both Hordeum and Chenopodium were considerably more abundant on grazed plots (Table 1). Potentilla norvegica, Iva xanthifolia, Chenopodium album, Hordeum jubatum and Polygonum achoreum were all dominants on the grazed plots.

The dams and consequent reservoirs on the mainstem Missouri River were constructed for flood control, hydroelectric power, irrigation, downstream navigation, recreation, and wildlife habitat. The land area surrounding these reservoirs between high and low water levels (shore) supports a mosaic of vegetation that responds to fluctuating water levels, to cattle grazing, or to both. Shore vegetation is important in providing some habitat for terrestrial wildlife, spawning habitat for certain fish species, protection from accelerated erosion, grazing habitat for cattle, and it enhances the aesthetic quality of the shore environment. Thus, the major uses of the reservoir system, listed above, have added to them additional uses tied directly to the well-being of the reservoir shores. Just as the major uses of the reservoir system can be maximized one at a time, the uses made of the shore vegetation can only be maximized one at a time.

Cattle grazing is indeed one of the uses for which shore 
vegetation is intended, but not the sole use. While stocking rates are explicit, or implicit, in leases to grazers, it is well known that animals concentrate and exert more influence near a water supply than over most of the upland range. Results of the present study show rather clearly the impact of cattle grazing on shore vegetation of Lakes Oahe and Sakakawea. These results are consistent with observations made over a much larger area of the shores of these lakes. It is desirable to have shore vegetation present and to persist over a period of years. Assuming shore vegetation is sufficiently important to include in an overall management plan, the following suggestions are made to enhance shore vegetation. Grasses such as Phalaris arundinacea (reed canary grass), Alopecurus arundinaceus, Alopecurus aequalis (shortawn foxtail), and Agropyron smithii grow well on many shore sites. These species can be seeded to accelerate succession beyond the early seral stages (Hoffman and Stanley, unpublished data). Shore vegetation exhibits its greatest development when not perturbed by large fluctuations of water levels, or closely cropped by grazing cattle. Once established, the grasses listed above, along with a number of other species, withstand considerable inundation (Hoffman and Stanley, unpublished data). The volume of the six reservoirs of the mainstem Missouri River is large; it would be possible to minimize water level fluctuations within one reservoir each year with the remaining five reservoirs taking up the additional input of water during the spring and letting out more water during the late summer. Along with a program of rotational, or restricted, grazing, the minimal water level fluctuation would permit considerably more vegetation development than occurs presently. Two consecutive years of minimal water level fluc- tuations and restricted grazing would be desirable for a given reservoir shore. This regime could be rotated among the six reservoirs and ultimately provided shore vegetation of a higher quality than currently exists. There would be an added benefit of some predictability in the development of shore vegetation. At present, one cannot predict from year to year what the shore vegetation at a given site will be unless it was neither inundated nor grazed the previous year.

\section{Literature Cited}

Daubenmire, R. 1959. A canopy-coverage method of vegetational analysis. Northw. Sci. 33: 43-64.

Gill, C.J., and A.D. Bradshaw. 1971. The landscaping of reservoir margins. J. Inst. Landscape Arch. 95: 31-34.

Hoffman, G.R., and L.D. Stanley. 1977. Artificial establishment of vegetation and effects of fertilizer along shorelines of Lakes Oahe and Sakakawea, mainstem Missouri River reservoirs. p. 95-109 In: Great Lakes Vegetation Workshop Proceedings, P. Wise and D. Mussulman, eds. Great Lakes Basin Commission, Ann Arbor, Mich.

Kelting, R.W., and W.T. Penfound. 1950. The vegetation of stock pond dams in central Oklahoma. Amer. Midl. Natur. 44: 69-75.

Magadza, C.H.D. 1970. A preliminary survey of the vegetation of the shore of Lake Kariba. Kirkia 7: 253-267.

Tiemeier, O.W. 1951. Studies on Kanopolis Reservoir. Trans. Kansas Acad. Sci. 54: 175-189.

U.S. Army Corps of Engineers. 1971. Garrison project area-capacity tables. Omaha District (mimeo. report), 12 p.

U.S. Army Corps of Engineers 1972. Oahe project area-capacity tables. Omaha District (mimeo. report), 12 p.

Van Bruggen, T. 1976. The vascular plants of South Dakota. Iowa State Univ. Press. $538 \mathrm{p}$.

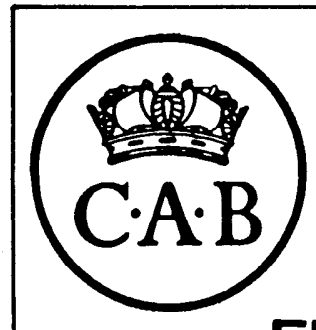

\section{HERBAGE ABSTRACTS}

(grasses, pastures, rangelands, and fodder crops)

\section{FIELD CROP ABSTRACTS}

(annual field crops)

for coverage of the world literature on agricultural research

For specimen copies of these computer-produced monthly journals and for lists of annotated bibliographies and other publications write to:

\author{
Commonwealth Bureau of \\ Pastures and Field Crops \\ Hurley, Maidenhead, \\ Berks SL6 5LR, UK
}

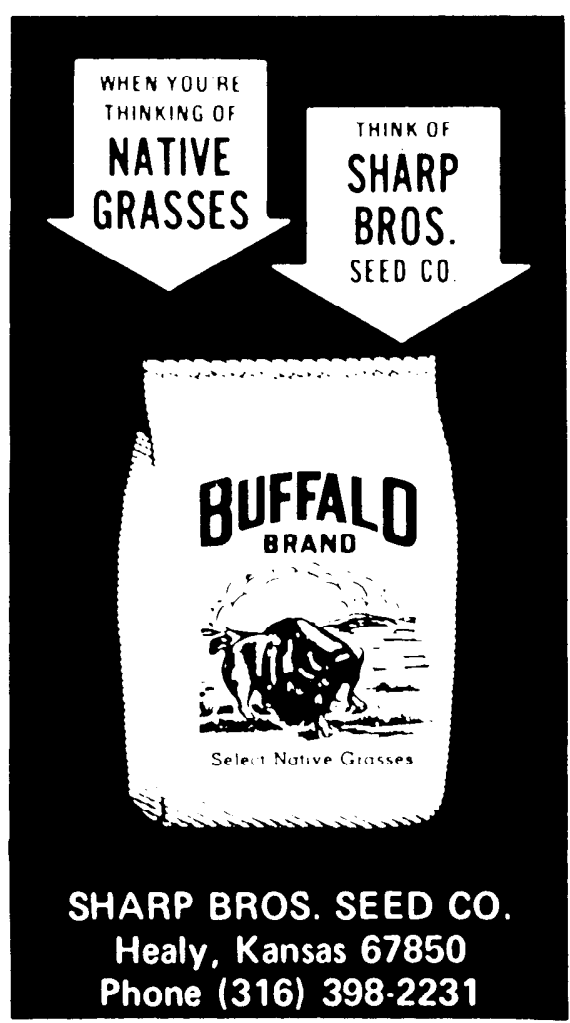

\section{CLYDE ROBIN}

\section{NATIVE SEEDS}

